\title{
Mycotrophic capacity and diversity of native arbuscular mycorrhizal fungi isolated from degraded soils
}

\author{
Winston Franz Ríos-Ruiz*i(i); Lleny Barrios-López; José Carlos Rojas-Garcíaid \\ Renzo Alfredo Valdez-Nuñez \\ Universidad Nacional de San Martín - Tarapoto; Jr. Maynas 177, Tarapoto, San Martín, Perú.
}

Received May 11, 2018. Accepted January 29, 2019.

\begin{abstract}
Arbuscular mycorrhizal fungi (AMF) are organisms that form mutualistic associations with most plants, favoring their development, especially those located in degraded areas. In order to identify the different predominant native AMF morphotypes, and determine the percentage of colonization, and spore density in soils of the Cumbaza sub-basin in San Martin, Peru, soil samples were taken from degraded areas of Chirikyacu, Vista Alegre, El Chontal, San Antonio de Cumbaza, Aucaloma and Shapumba, and they were associated with 4 legumes cover crops among them, Cajanus cajan, Canavalia ensiformis, Crotalaria juncea and Vigna unguiculata. A completely random design was used, considering 6 zones and 4 legumes with 3 replications. The results showed that the treatments with legumes had greater influence in the mycorrhizal colonization in comparison with the zones of study, being Vigna unguiculata the one that had greater colonization (75\%). However, the number of spores was influenced mainly by the zones, where the Aucaloma treatment had the highest number $(252$ spores / $10 \mathrm{~g}$ of soil). Eleven native AMF morphotypes were identified, being those of the genus Acaulospora the most predominant.
\end{abstract}

Keywords: cover crops; degraded soil; legume; spores; symbiosis.

\section{Introduction}

Arbuscular mycorrhizal fungi (AMF) form mutualistic symbiotic associations with roots of approximately $80-90 \%$ of higher plants on the planet and in all habitats of the earth (van der Heijden et al., 2015). The plant provides the fungus with products of photosynthesis and the fungus supplies nutrients to the plant, in particular immobile nutrients such as phosphorus (Cardoso et al., 2017; Ma et al., 2019). They can also increase plant resistance against abiotic or biotic stress (Islas et al., 2016), exercise control over pathogens (Mora-Romero et al., 2015; Alvarado-Herrejón et al., 2019), increase the proportion of carbohydrates in the root (Chen et al., 2018) and participate in the formation of soil aggregates (Peng et al., 2013). Its extensive extra radical mycelium favors the link between the plant and the soil (Rojas-Mego et al., 2014) allowing to explore a greater volume of soil than the roots, which increases the absorption of nutrients for the plant (Rajtor and
Piotrowska-Seget, 2016).

The study of the diversity of AMF in natural conditions is carried out through the selection and quantification of the number of spores, as well as the identification of morphotypes associated with a specific plant. Native AMF selected from areas with particular soil and climate conditions can be used as inoculants, with a better chance of adapting to degraded areas (LópezGómez et al., 2015). The AMF obtained in this way when they multiply and reintroduce in certain areas can increase their richness and together with the installation of legumes favor the recovery of degraded soils. The legumes (PeñaVenegas and Arias, 2009) associated with AMF improve the physical characteristics (decompaction of soils), chemical (accumulation of organic matter and greater viability of nutrients) and biological (greater activity and microbial diversity) of the soil, in addition to reduce the mortality rate in plants (Duval et al., 2015). While recent

\footnotetext{
How to cite this article:

Ríos-Ruiz, W.F.; Barrios-López, L.; Rojas-García, J.C.; Valdez-Nuñez, R.A. 2019. Mycotrophic capacity and diversity of native arbuscular mycorrhizal fungi isolated from degraded soils. Scientia Agropecuaria 10(1): 99-108.
} 
studies have investigated the effects of soil disturbances on the composition and richness of AMF in both agricultural soils (Mickan et al., 2018) and pasture soils (Stover et al., 2018), there is little information on whether soil disturbance from migratory agriculture influences spore numbers and AMF colonization in acid $\mathrm{pH}$ soil areas.

Currently, the biological properties of the soil have become important criteria to evaluate their use and management (VallejoQuintero, 2013). These are considered a new and emerging tool for the maintenance and restoration of soils, since they act as an index of soil fertility and their symbiotic interactions with plants favor the assimilation of nutrients (Singh, 2015). The presence, in turn, of certain plant species, product of plant succession processes, reveals soil fragmentation, which leads to changes in communities of microorganisms such as AMF (Majewska et al., 2018). The San Martín region, Peru, product of unsustainable anthropogenic actions, such as migratory agriculture, presents areas with soils that have lost their fertility (Carranza et al., 2012; Ravikumar et al., 2017), demonstrated by the presence of expansive herbaceous species such as Pteridium aquilinum and Imperata brasiliensis. The recovery of these areas with cover crops may require the restoration of beneficial soil microorganisms, such as AMFs, and therefore more knowledge is needed about the diversity of AMFs and their interaction with plant communities.

Therefore, the objective of the present work was to select different morphotypes of native arbuscular mycorrhizal fungi predominant in degraded soils of the Cumbaza sub-basin and determine their mycorrhizal potential associated with legume plants. The hypothesis was that there is a great diversity of AMF in degraded areas of the Cumbaza sub-basin, whose number and mycrotrophic capacity is increased by multiplying in trap plants. This would allow an adequate number of AMF propagules to be re-introduced into areas of degraded soils. The information obtained will contribute to a better understanding of the interactions between AMF, legumes and soil, in order to improve the restoration strategies of native plants in disturbed areas.

\section{Materials and methods}

\subsection{Places of study and collection of soil} samples

Soil samples were collected in degraded areas of 6 zones of the Cumbaza sub-basin located in the provinces of Lamas and San
Martin, Peru. These areas were Chirikyacu (6²9.065'S; $\left.76^{\circ} 22,038^{\prime} \mathrm{W}\right)$, Vista Alegre (6²2.830'S; $\left.76^{\circ} 31.132 \mathrm{~W}\right)$, El Chontal (6 $\left.20.435^{\prime} S ; 6^{\circ} 30.769 ' \mathrm{~W}\right)$, San Antonio de Cumbaza $\quad\left(6^{\circ} 24.286 ' S\right.$; $\left.\quad 76^{\circ} 25.181 ' \mathrm{~W}\right)$, Aucaloma $\left(6^{\circ} 26.296\right.$ 'S; $\left.76^{\circ} 25.440^{\prime} \mathrm{W}\right)$ and Shapumba $\quad\left(6^{\circ} 25.747^{\prime} \mathrm{S} ; \quad 76^{\circ} 28.977^{\prime} \mathrm{W}\right)$. Cumbaza sub-basin is characterized by presenting areas of altitude between 410 and 1199 meters above sea level, with shallow, acid and low fertility soils. These are classified as inceptisols, entisols and alfisols. The average annual rainfall is 1200 $\mathrm{mm}$, the average temperature is $26^{\circ} \mathrm{C}$ and the relative humidity is $70 \%$, considering these characteristics as an ecosystem of tropical dry forest and tropical premontane rainforest (Figure 1).

For the sampling of the soil, parcels of 2500 $\mathrm{m}^{2}$ were selected in each area where the plants of Shapumba (Pteridium aquilinum) and Cashaucsha (Imperata brasiliensis) predominated and are indicators of degraded soils. Sampling was randomized in a zig-zag fashion, taking $1 \mathrm{~kg}$ of soil at a depth of $0-20 \mathrm{~cm}$ in 10 equidistant points (approximately $10 \mathrm{~m}$ ), making a total of 10 sub samples per zone.

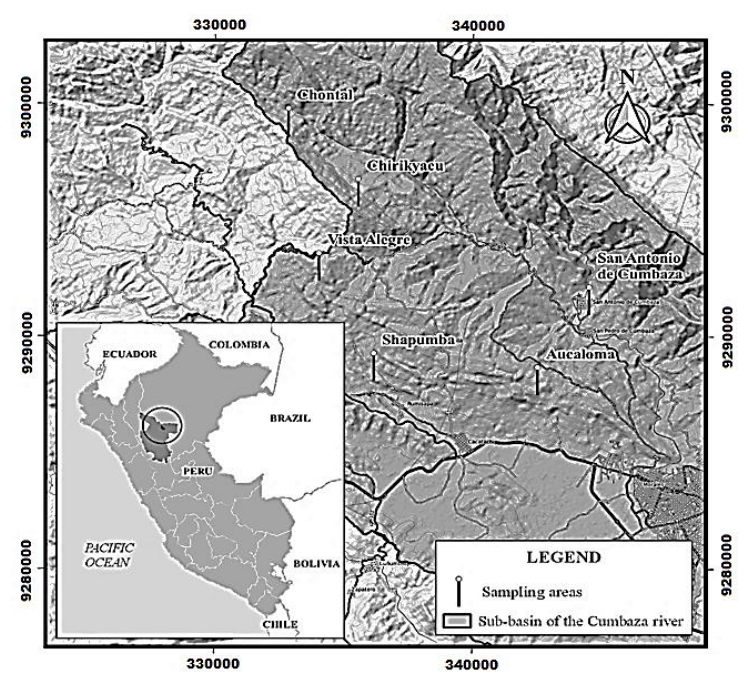

Figure 1. Map of the Cumbaza sub-basin that indicates the location of the 6 soil sampling zones.

The soil samples were homogenized and deposited in polyethylene bags and labeled with the name of the area and the collection date. Two fractions of each sample were separated, one for the selection of AMF spores and the other for physicochemical analysis. The remaining part was used as a substrate for the development of trap plants (legume cover crops). The soil samples were collected on April and May 2016, a season considered rainy, with rainfall ranging from 55 to $255 \mathrm{~mm}$ in the collection areas (SENAMHI, 2016). 
Table 1

Physicochemical characteristics of soils in areas of the Cumbaza sub-basin

\begin{tabular}{|c|c|c|c|c|c|c|c|c|c|c|}
\hline \multirow[b]{2}{*}{ Areas } & \multirow[b]{2}{*}{$\mathrm{pH}$} & \multirow{2}{*}{$\begin{array}{c}\text { EC } \\
\mu \mathrm{s} / \mathrm{cm}\end{array}$} & \multirow[b]{2}{*}{$\begin{array}{l}\mathrm{N} \\
\%\end{array}$} & \multirow[b]{2}{*}{$\begin{array}{r}\text { OM } \\
\%\end{array}$} & \multirow[b]{2}{*}{$\begin{array}{c}\text { P } \\
\text { ppm }\end{array}$} & \multirow[b]{2}{*}{$\begin{array}{c}\mathrm{K} \\
\mathrm{ppm}\end{array}$} & \multicolumn{3}{|c|}{ Mechanical analysis } & \multirow{2}{*}{$\begin{array}{l}\text { Textural } \\
\text { class }\end{array}$} \\
\hline & & & & & & & $\begin{array}{c}\text { Sandy } \\
\%\end{array}$ & $\begin{array}{c}\text { Silt } \\
\%\end{array}$ & $\begin{array}{c}\text { Clay } \\
\%\end{array}$ & \\
\hline Chirikyacu & 3.78 & 171.3 & 0.217 & 4.47 & 3.48 & 110.76 & 42 & 36 & 22 & Loam \\
\hline Chontal & 3.99 & 156.7 & 0.228 & 4.56 & 4.68 & 52.63 & 38 & 33 & 28 & Sandy loam \\
\hline Aucaloma & 4.62 & 88.8 & 0.184 & 3.67 & 4.62 & 50.74 & 35 & 33 & 33 & Clayish loam \\
\hline Shapumba & 4.47 & 57.8 & 0.129 & 2.57 & 4.18 & 28.61 & 54 & 28 & 18 & Sandy loam \\
\hline
\end{tabular}

Analysis methodologies: pH (potentiometry, soil:water ratio 1:2.5, SI Analytics Lab 850 potentiometer, Germany), EC = Electrical conductivity (Conductimetry, soil:water ratio 1:2.5, SI Analytics Lab 960, Germany), N = Nitrogen (Micro Kjeldahl), OM = Organic matter (Walkley and Black), $\mathrm{P}=$ extractable phosphorus (modified Olsen), $\mathrm{K}=$ (By extraction of ammonium acetate and quantification in atomic absorption spectrophotometer GBC, SavantAA, Australia) and Texture (Bouyoucos Hydrometer).

\subsection{Physicochemical characteristics of soils and spore density}

The physicochemical characteristics of the soils collected are shown in Table 1, where the high acidity and low fertility of these soils can be observed. Table 2, on the other hand, shows the number of AMF spores isolated from the soils of the study areas.

Table 2

Number of AMF spores isolated from soils in areas of the Cumbaza sub-basin

\begin{tabular}{lc}
\hline Areas & N $^{\circ}$ of spores / $10 \mathrm{~g}$ of soil* \\
\hline Chirikyacu & 25 \\
Vista Alegre & 20 \\
Aucaloma & 13 \\
El Chontal & 13 \\
Shapumba & 28 \\
San Antonio de Cumbaza & 17 \\
* Determined by the methods described by Gerdemann \\
and Nicolson (1963) and by Schenck and Pérez (1990).
\end{tabular}

\subsection{Trap plants and multiplication of AMF}

The soils collected from each of the zones under study were crushed and screened separately. These, with the addition of vermiculite in a ratio of $1: 1$, became the substrate for the development of trap plants. The vermiculite was washed and sterilized previously in an autoclave (Fravill, AVDA50, Peru) at $121{ }^{\circ} \mathrm{C}$ for 1 hour. For the sowing $3.5 \mathrm{~kg}$ pots were used, each of which contained substrate with soil from each zone and were placed under nursery conditions. Disinfected seeds were used (with alcohol $(70 \%)$ for 1 minute, rinsing with distilled $\mathrm{H}_{2} \mathrm{O}, \mathrm{NaOCl}(2 \%)$ for 5 minutes and rinsing with distilled $\mathrm{H}_{2} \mathrm{O}$ ) of 4 legumes adapted to tropical climates: Puspino (Cajanus cajan), Canavalia (Canavalia ensiformis), Crotalaria (Crotalaria juncea) and Caupi (Vigna unguiculata). The plants were kept in greenhouse conditions for 2.5 to 3 months, being watered until maintaining the humidity in field capacity. Nutritious solution of Hoagland without phosphorus was applied every 2 weeks. Irrigation was suspended between 70 and 80 days to stimulate the multiplication of AMF spores. At the end of this period, soil samples from the pots were dried and then sieved, keeping $500 \mathrm{~g}$ for further analysis. On the other hand, the roots of each of the legumes were washed with abundant water and cut into segments of approximately $2 \mathrm{~cm}$ in length. Then, these were placed in $50 \mathrm{ml}$ falcon tubes adding alcohol $(70 \%)$ for preservation.

\subsection{Density of spores}

The isolation of spores from the soil samples was carried out according to the wet sieving and decantation method, proposed by Gerdemann and Nicolson (1963) with certain modifications. To do this, a sample of $10 \mathrm{~g}$ of soil was sieved through sieves of $710 \mu \mathrm{m}$ and $53 \mu \mathrm{m}$ (ELE International, USA) in sequence, to isolate spores of different sizes. They were then placed in $50 \mathrm{ml}$ Falcon tubes and resuspended with distilled $\mathrm{H}_{2} \mathrm{O}$ for centrifugation (in Hettich centrifuge, Rotofix 32 A, Germany) at $3500 \mathrm{rpm}$ for 5 minutes. A second centrifugation was performed in aqueous sucrose solution $(70 \%)$ at $3500 \mathrm{rpm}$ for 5 minutes. This stage was repeated twice. The spores were quantified according to the method proposed by Schenck and Pérez (1990). Thus, $10 \mathrm{ml}$ of each sample processed by the sieving and decanting technique was taken and deposited in a concentric plate to facilitate spore counting. The spores were counted with the help of a manual counter and a binocular stereomicroscope (Carl Zeiss, Stemi 305, Germany) with a 40-fold increase.

\subsection{Mycorrhizal colonization}

Root staining of the legume cover crops was carried out according to the methodology of Vierheilig et al. (1998). Root samples that were preserved in alcohol $(70 \%)$ were washed with running water and heated in a water bath (Selecta, Precisdig $12 \mathrm{I}$, Spain) at $90{ }^{\circ} \mathrm{C}$ with a solution of $\mathrm{KOH}$ (10\%) for 40 minutes. Then, $\mathrm{H}_{2} \mathrm{O}_{2}(10 \%)$ was added until clarified. To follow, blue ink (Parker, Quink blue, France) was added for 60 seconds at $90^{\circ} \mathrm{C}$ in a mary bath (Selecta, Precisdig 12 I, Spain). Finally, the stained roots were preserved in lactoglycerol for further evaluation. The determination of the percentage of mycorrhizal colonization was carried out according to the methodology 
of Giovannetti and Mosse (1980). For this, the rootlets conserved in lactoglycerol were randomly distributed in a gridded Petri dish $(1.27 \times 1.27 \mathrm{~cm})$, observing the binocular stereomicroscope (Carl Zeiss, Stemi 305, Germany) fungal structures of the AMF (hyphae, vesicles, arbuscules, spores). In each visual field the intersection of the roots with the horizontal line was observed, noting the presence or absence of mycorrhizal colonization of the root segment located on the grid line.

\subsection{Isolation and identification of native AMF}

For the development of this activity, the spores were placed on a clock plate and observed in the binocular stereomicroscope (Carl Zeiss, Stemi 305, Germany). With the help of a dissection needle, the spores were grouped according to the morphotypes, taking into account the morphological characteristics of shape, color and diameter, and then extracted with the help of a micropipette. The spores of the predominant morphotypes of each zone and of each legume was separated and placed on slides using polyvinyl alcohol and glycerol lactic acid (PVLG) and PVLG mixed with Melzer's reagent (1:1 v/v). Each preparation was kept at room temperature for 72 hours, and then observed in a binocular microscope (Carl Zeiss, Primo Star, Germany) at $100 \mathrm{X}$ and $400 \mathrm{X}$. With the help of the Axio Vision system from Carl Zeiss, all the morphological characteristics were evaluated according to the parameters used in the illustrated arbuscular mycorrhizae catalog of the Colombian Amazon (Peña-Venegas et al., 2006) and description of the species in the international collection of vesicular arbuscular mycorrhizal fungi from the University of West Virginia, USA (INVAM, 2017).

\subsection{Experimental design and evaluation of variables}

The present work was developed using a completely randomized design (DCA), with a factorial arrangement of $6 A \times 4 B$, considering factor $A$, areas of the Cumbaza subbasin, which include: Chirikyacu, Vista Alegre, Aucaloma, El Chontal, Shapumba and San Antonio de Cumbaza and factor B, legume cover crops, among them: $\mathrm{Ca}$ navalia ensiformis, Crotalaria juncea, Vigna unguiculata and Cajanus cajan. The interaction of each of the factors gave rise to 24 treatments, with 3 repetitions, which makes a total of 72 experimental units. All the data obtained were subjected to analysis of variance. Once the homogeneity of the variances and the normal distribution of the data were verified, the means were compared using Tukey's multiple range test. For all cases, a significance level of $p<0.05$ was used with $n=3$. The data was analyzed with the SAS 9.2 program (SAS Institute Inc., 2008). To normalize the distribution of the data and stabilize the variances, the data expressed in percentage (mycorrhizal colonization) and quantifiable data (number of spores) were transformed to arcsine $V_{x}$ and $\log (\mathrm{x})$, respectively.

In relation to the evaluation of the variables, the percentage of colonization of roots was calculated according to the methodology proposed by Giovannetti and Mosse (1980), using the following formula: Mycorrhizal colonization $(\%)=$ number of colonized segments / total number of evaluated segments $\times 100$. The evaluation of the number of spores and the selection of predominant morphotypes was carried out in the third month of the experiment, with viable spores quantified in $10 \mathrm{~g}$ of soil and morphotypes found in a greater number of individuals (spores) in a determined sample of soil.

\section{Results and discussion}

\subsection{Mycorrhizal colonization}

According to the analysis of variance, it was observed that only the legume factor significantly influenced the mycorrhizal colonization ( $p<0.05$ and $R^{2}=61 \%$ ), but not the zones factor. However, according to the mean comparison analysis $(p<0.05)$ (Figure 2), the legume roots of Chirikyacu showed the highest colonization $(74.32 \%)$ and the lowest colonization (64.27\%) which was observed in the roots of the Aucaloma area.

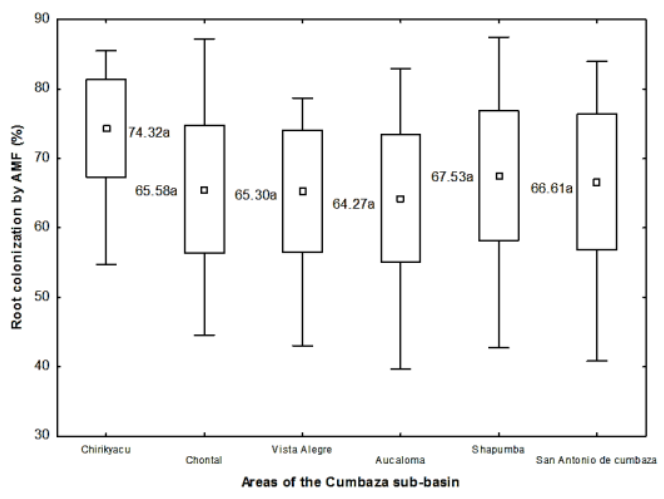

Figure 2. Box and whisker plot shows the mean, range and significant variation of root colonization by AMF in the different study areas. Different letters indicate a significant difference in the level of 0.05 .

These results show high levels of colonization that can be closely linked to the $\mathrm{pH}$ of the soil and to the lower amount of available phosphorus present in the soils of 
the different zones under study (Table 1). Corpoica (1998) found mycorrhization values of $50 \%$ to $84 \%$ in areas with low pH soils (3.5 to 4.2 ), results that agree with those obtained in the present work. In relation to phosphorus, some studies report an increase in mycorrhizal colonization in soils with low levels of available phosphorus (Chen et al., 2008). In the present work, in the Chirikyaku area, less available phosphorus was found (3.48 ppm) (Table 1), greater mycorrhizal colonization was also observed (74.32\%) (Figure 2).

Recently Ma et al. (2019), reported that under low phosphorus soil conditions the inoculation of AMF improved yield and zinc concentrations in wheat grain. On the other hand, in an AMF propagation trial using trap plants, but in this case corn, AlvaradoHerrejón et al. (2019) determined that corn plants grown in pots with sterile substrate, without phosphorus supplementation but supplemented with soil containing native AMF communities, reached the flowering stage unlike uninoculated corn plants that did not flower. This demonstrates the importance of knowing the type of vegetation and the behavior of AMF native to a given area, in order to establish future strategies for restoring degraded soils (Stover et al., 2018), as is the case of the soils of the Cumbaza sub-basin, the study area of this paper.

Regarding the effect of legumes on mycorrhizal colonization, significant differences were observed between Vigna unguiculata (75.01\%), Crotalaria juncea $(73.73 \%)$ and Canavalia ensiformis $(67.66 \%)$, in relation to Cajanus cajan (52.68\%) that had the least colonization (Figure 3 ).

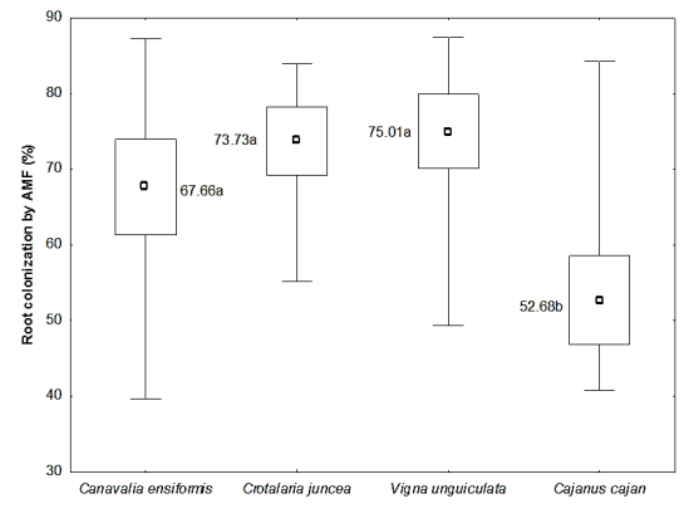

Legume cover crops

Figure 3. Box and whisker plot shows the mean root colonization (\%) by AMF and its significant variation according to the legume cover crop used as a trap plant. Different letters indicate a significant difference in the level of 0.05 .

These data are consistent with that reported by other authors such as Martín et al. (2007) that found $62.69 \%$ mycorrhizal colonization in roots of Canavalia ensiformis and Pérez-Luna et al. (2012) that reported $80.3 \%$ of colonization in legumes. Similarly, Higo et al. (2015) compared in an experiment under greenhouse conditions the yield of four cover crops between grasses and legumes (pea, hairy vetch, wheat and barley), finding differences in the percentage of root colonization by AMF between crops. The authors attributed these differences to the host selectivity. Thougnon-Islas et al. (2014), on the other hand, evaluated the mycotrophyc capacity of native AMF in soils of 7 zones in Buenos Aires (Argentina) using trap plants and observed that mycorrhizal colonization varied from $4.8 \%$ to $56.7 \%$, without finding a uniform pattern among areas due to the edaphic differences existing among them. Molecular analyzes performed by Turrini et al. (2018) revealed that the growth and nutrition of the plants (Allium cepa, Capsicum annuum and Lactuca sativa) were significantly affected by the diversity of native AMF that colonized the roots of the plants, varying their yield. Both native and non-native plant species influence the physicalchemical properties of the soil and thus the colonization of AMF (Majewska et al., 2018). According to Basu et al. (2018), the biochemical mechanisms that occur between the symbionts directly affect the process of colonization and the formation of mycorrhizal structures, as well as the carbohydrate ratio and tensile strength of the plant root (Chen et al., 2018). GarcíaGonzález et al. (2016) pointed out that the mycorrhizal structures formed (spores, hyphae, vesicles and arbuscules) and observed in the present work (Figure 4), fulfill different functions during the symbiosis, such as: reproduction, propagation, infection, absorption, reserve and exchange of nutrients between the plant and the fungus.

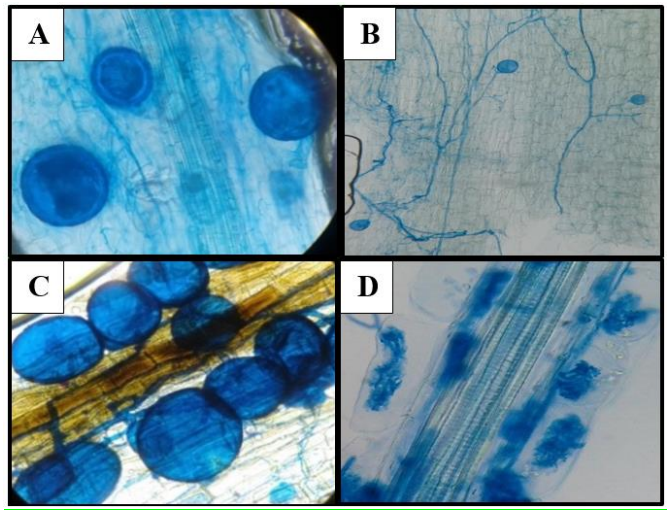

Figure 4. AMF structures in legume roots observed under a binocular microscope. A) Spores, B) Intraradical hyphae, C) Vesicles, D) Arbuscules. 


\subsection{Number of native AMF spores}

When performing the analysis of variance, both the zones factor and the legume factor showed independent and significant effects on the number of spores $\left(p<0.05\right.$ and $R^{2}=$ $54 \%)$. In relation to the effect of the zones on the number of spores, it was verified that the area of Aucaloma had a higher number of spores (252 spores / $10 \mathrm{~g}$ of soil) and, the area of Chirikyacu however had the lowest number (190 spores / $10 \mathrm{~g}$ of soil) (Figure 5).

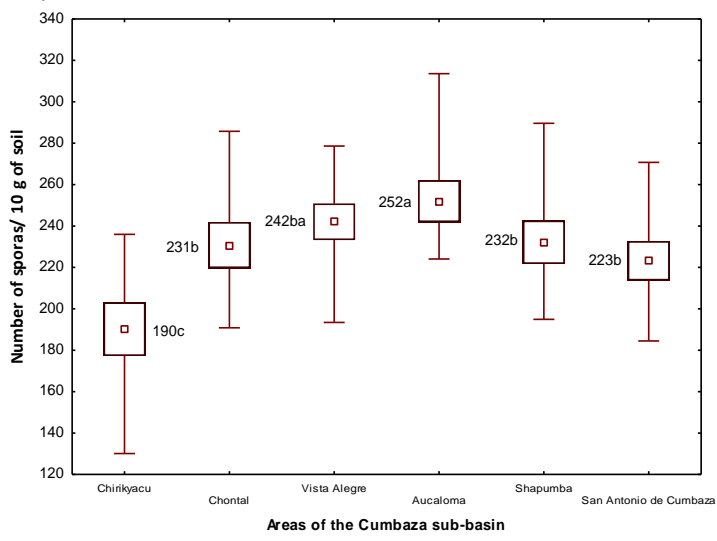

Figure 5. Box and whisker plot shows the mean, range and significant variation of the number of AMF spores in the different study areas. Different letters indicate a significant difference in the level of 0.05 .

According to García-González et al. (2016) the physicochemical characteristics of soils can generate variations in the number of spores. The soil analysis of the study areas shows differences in $\mathrm{pH}$, fertility level in phosphorus and nitrogen and in physical parameters such as texture and structure (Table 1), factors that could be influencing the variation in the number of spores described in the present study. Influences of the climatic characteristics of the sites on the number of spores were observed by Haro et al. (2018), who after selecting and identifying AMF from 6 sites in Burkina Faso, West Africa, found a significant negative correlation with respect to the level of phosphorus in the soil, reached between 339-2181 spores per $100 \mathrm{~g}$ of soil. Becerra et al. (2014), meanwhile, affirmed that, in addition to climatic factors, the production of AMF spores also depends on the type of host plant. The authors evaluated soils of 4 plants of the Chenopodiaceae family finding different numbers of spores in each of them (between 3 and 1162 per $100 \mathrm{~g}$ of soil). Differences in spore numbers were also observed by Majewska et al. (2018), studying the interaction of AMF with invasive exotic plants and expansive native plants and their relationship to soil properties. In the Cumbaza sub-basin, where soils were obtained for the development of this work, invasive species of Pteridium aquilinum and Imperata brasiliensis predominate, which have expanded in this area due to low soil fertility (Suazo-Ortuño et al., 2015), so understanding the mechanisms of interaction between symbionts is essential to establish soil restoration programs in degraded areas.

In relation to the variation in the number of spores produced in the trap plants, compared to those found in the field (28-32 spores per $10 \mathrm{~g}$ of soil, Table 2), a considerable increase was observed, varying between 190-252 spores per $10 \mathrm{~g}$ of soil (Figure 5). Similar results were observed by Thougnon-Islas et al. (2014) who found between 80-1175 spores / $100 \mathrm{~g}$ in the substrate of trap plants, a greater number, according to the authors, than those found in the field. It is likely, then, that the mycorrhizal propagules in the soil samples were mainly segments of hyphae and colonized roots, instead of spores.

In relation to the effect of the legume cover crops on the number of spores, significant differences were found between Canavalia ensiformis, Crotalaria juncea and Cajanus cajan, with respect to Vigna unguiculata that had the smallest number of spores (Figure 6).

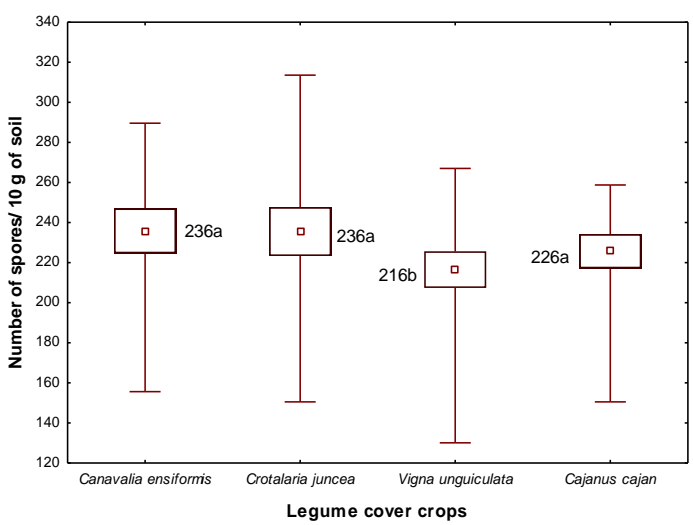

Figure 6. Box and whisker plot shows the mean, range and significant variation of the number of AMF spores in different legume cover crop. Different letters indicate a significant difference in the level of 0.05 .

The climatic factors of the study area could be influencing the presence of AMF propagation structures. The soils used in the installation of trap plants were extracted in a rainy period. Oliveira and Oliveira (2005) when studying the seasonal dynamics of AMF of 2 fruit species, in an upland ecosystem in the central Amazon, observed a significant positive correlation between the increase in the number of AMF 
spores with the rainy period, concluding that both the colonization and the sporulation of AMF are seasonal and depend on the species of host plant, the climatic factors and the chemical composition of the soil of a given area.

\subsection{Predominant native AMF diversity}

According to the morphological characteristics observed in the AMF spores of the soils of the Cumbaza sub-basin associated with 4 legume cover crops, the identification and selection of 11 predominant native morphotypes belonging to 4 genera (Ambispora, Acaulospora, Glomus and Rhizoglumus) was achieved. The most predominant was the genus Acaulospora with 8 morphotypes (Table 3). Bearing in mind that not all AMF species have the same capacity to form spores in a given period (Schenck and Pérez, 1990), it is very likely that other AMF genera exist in the area studied, not described in the present work.

Comparing the number of spores found in the soils of the different collection areas (Table 1) with respect to the number of spores of the different morphotypes found in the trap plants (Table 3 ), an increase of spores of up to $900 \%$ was observed and a wide diversity of efficient AMF morphotypes in degraded soils, which confirms the proposed hypothesis, hence the importance of these studies that support the application of techniques that use inoculants in soil recovery programs.

This report is consistent with that found by Lopes et al. (2016) in soils with acid pH and multiplied in trap plants using Brachiaria decumbens where they observed a total of 15 AMF morphotypes being the majority belonging to the genus of Glomus and Acaulospora. Pérez-Luna et al. (2012), in turn, reported morphotypes in acid soils in Mexico, in corn plots associated with cover crops, with the genera Glomus and Acaulospora being the most abundant with 11 and 8 morphotypes, respectively. Banni and Faituri (2013) pointed out that the genera Glomus and Acaulospora adapt better to the stressful conditions of acid soils. Likewise, it was observed that in trap plants there is a succession pattern in the sporulation of AMF, with Glomus species being the first to sporulate, while Acaulospora species do so later than a seasonal period (Oehl et al., 2003). Stürmer and Siqueira (2011) when studying the richness and abundance of AMF spores in soils of 6 areas with different land uses (mature virgin forests and converted pasture sites, crops, agroforestry systems, secondary forests, young and old), in the Amazon region of Brazil. They observed that the fungal communities were dominated by the Glomus species, although the Acaulospora species produced more abundant sporulation, which shows that the cultural practices adopted in this region maintains a great diversity of AMF in the different areas. Alvarado-Herrejón et al. (2019), on the other hand, identified twentyseven morphotypes of AMF at the species level, which belonged mainly to the families of Gigasporaceae, Glomeraceae and Acaulosporaceae. The wide distribution of the genera Acaulospora and Glomus observed in the present study coincides with the reports of the majority of the researches carried out on degraded soils (Sousa et al., 2014, Torres-Arias et al., 2017; Stover et al., 2018).

Table 3 also shows that morphotypes 2 (Acauslospora ignota), had the highest abundance of spores with 923 individuals, being the most representative in this study. Morphotypes 1 reached a total of 430 individuals and morphotypes 3, 122 individuals. The morphotypes $4,5,6,7,8$ and 9 belonging to the genus Acaulospora had between 14 and 91 spores $/ 10 \mathrm{~g}$ of soil. In relation to the morphotypes 10 and 11 belonging to the genera Glomus and Rhizoglomus they had 110 and 28 individuals respectively. Coelho et al. (2014) found that the type of substrate used in plant development also causes variations in the production of AMF spores and infectious propagules. Likewise, spore production and the distribution of AMF communities are related to soil $\mathrm{pH}$ and micronutrient levels ( $\mathrm{Mn}$ and $\mathrm{Zn}$ ) (Alguacil et al., 2016). Table 4 shows the structures of the spores of the different AMF morphotypes found in the present work.

Table 3

Total number of spores per predominant AMF morphotypes, obtained from each of the substrates of the different study areas where each of the legumes used as trap plants grew

\begin{tabular}{llllllllllll}
\hline Morphotypes & M1 & M2 & M3 & M4 & M5 & M6 & M7 & M8 & M9 & M10 & M11 \\
\hline $\begin{array}{l}N^{\circ} \text { of spores } I \\
10 \text { g of soil }\end{array}$ & 430 & 923 & 122 & 91 & 85 & 76 & 20 & 18 & 14 & 110 & 28 \\
\hline
\end{tabular}

AMF morphotypes: M1 = Ambispora appendiculata, M2 = Acaulospora ignota, M3 = Acaulospora rugosa, M4 = Acaulospora herrerae, M5 = Acaulospora sp. 1, M6 = Acaulospora sp. 2, M7 = Acaulospora foveata, M8 = Acaulospora tuberculata, M9 = Acaulospora sp. 3 , M10 = Glomus sp., M11 = Rhizoglomus sp. 
Table 4

Identification of predominant native morphotypes of the 6 zones of the Cumbaza sub-basin and the 4 legume cover crops used as trap plants

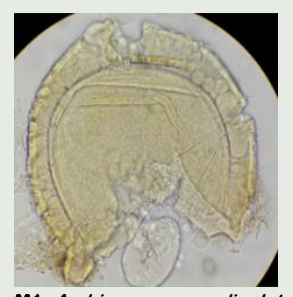

M1. Ambispora appendiculat

Color: yellow

Diameter: $170-390 \mu \mathrm{m}$

Number of walls: 03

Ornamentation: yes

Scar: yes

Suspension hypha: $\mathrm{no}$

Germination plate: no
Reaction in Melzer: yes

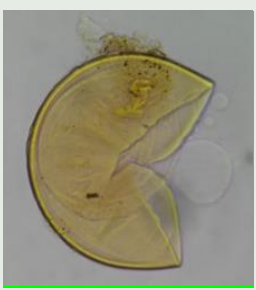

M2. Acaulospora ignota Color: light yellow Shape: Globose

Diameter: 60-95

Diameter: 60-95 $\mu \mathrm{m}$

Number of walls: 03

Ornamentatio

Scar: yes

Suspension hypha: no

Germination plate: no

Reaction in Melzer: yes

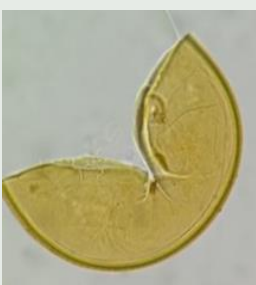

M3. Acaulospora rugosa Color: light yellow Shape: Globose

Diameter: $70-128 \mu \mathrm{m}$ Diameter: 70-128 $\mu \mathrm{m}$ Number of walls: 03 Scar: yes

Scar: yes Germination plate: $n$ Reaction in Melzer: yes

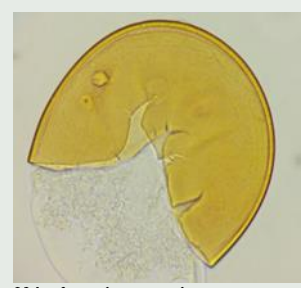

M4. Acaulospora herrerae Color: yellowish brown

Shape: spheric

Diameter: 50-112 $\mu \mathrm{m}$

Number of walls: 03

Ornamentation: yes

Scar: yes

Suspension hypha: no

Germination plate: $n$

Reaction in Melzer: yes

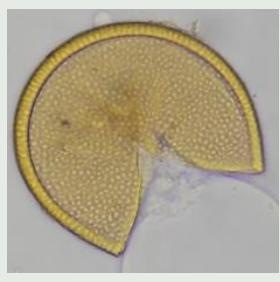

M5. Acaulospora sp. 1

Color: light yellow

Shape: spheric

Diameter: 70-112 $\mu \mathrm{m}$

Number of walls: 03

Ornamentation: yes

Scar: yes

Suspension hypha: no

Germination plate: no

Reaction in Melzer: yes

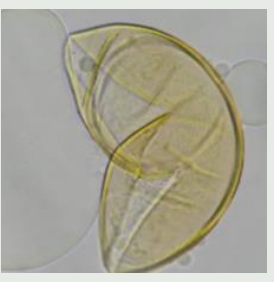

M6. Acaulospora sp. 2 Color: light yellow Shape: spheric

Diameter: 75-100 $\mu \mathrm{m}$

Number of walls: 03

Number of walls: 03

\section{car: no}

Suspension hypha: no

Germination plate: no

Reaction in Melzer: yes

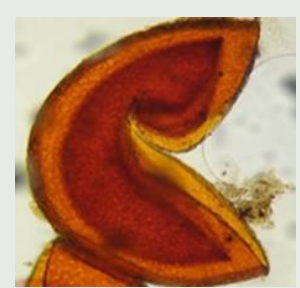

M7. Acaulospora foveat Color: reddish-brown Shape: spheric

Diameter: 300 a $400 \mu \mathrm{m}$

Number of walls: 03

Ornamentation: yes

Scar: yes

Suspension hypha: no

Germination plate: $n$

Reaction in Melzer: yes

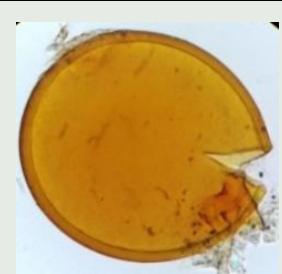

M10. Glomus sp.

Color: light brown

Shape: spheric

Diameter: 80-200 $\mu \mathrm{m}$

Ornamentation: no

Scar: no

Suspension hypha: no

Germination plate: $\mathrm{no}$

Reaction in Melzer: $n$

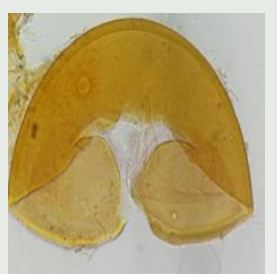

M8. Acaulospora tuberculata

Color: dark yellow

Shape: spheric

Diameter: 255-340 $\mu \mathrm{m}$

Number of walls: 03

Ornamentation:

Scar: yes
Sution: yes

Scar: yes

Suspension hypha: no

Germination plate: no

Reaction in Melzer: yes

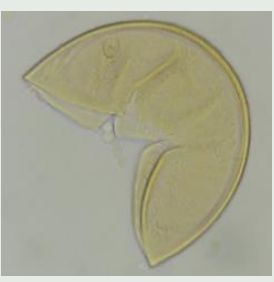

M9. Acaulospora sp. 3 Color: light yellow

Shape: spheric

Diameter: 220-320 $\mu \mathrm{m}$

Number of walls: 03

Ornem of walls:

\section{Scar: no}

Suspension hypha: no

Germination plate: no

Reaction in Melzer: yes

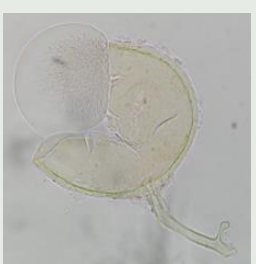

M11. Rhizoglomus sp.

Color: hyaline

Shape: globose

Diameter: $75-100$ um

Number of walls: 02

Ornamentation: no

Scar: no

Suspension hypha: si

Germination plate: no Reaction in Melzer: no 


\section{Conclusions}

As demonstrated in this study, AMF constitute an important component of soil in degraded areas. The knowledge of the diversity and richness of AMF is a priority to later understand the processes that allow its adaptation in certain environments and the setting of symbiosis with plants. The selection of predominant native AMF and its multiplication in trap plants are actions that favor the increase of spores that could then be reintroduced in the degraded areas and thus improve the development of the plants through a greater absorption of nutrients from the soil. The AMF morphotypes selected in this way could be used as inoculants of legume cover crops in the recovery processes of degraded areas, an activity that is also favorable for the environment.

\section{Acknowledgments}

To the National Council of Science and Technology, CIENCIACTIVA (CONCYTEC, Peru), for the financing granted within the framework of the project development "Restoration of degraded soils by migratory agriculture using beneficial microorganisms associated with cover plants in the protection zone of the Cumbaza sub-basin, in San Martin, Peru". Project executed in the Agricultural Microbiology Laboratory "Raúl Ríos Reategui" of the Faculty of Agrarian Sciences of the National University of San Martin - Tarapoto. Also, to Dr. Bruno Tomio Goto, professor at the Federal University of Rio Grande do Norte, Brazil, for the support in the taxonomic identification of AMF.

\section{ORCID}

W.F. Ríos-Ruiz (ID) https://orcid.org/0000-0002-6513-3379 J.C. Rojas-García (iD https://orcid.org/0000-0002-5273-0182 R.A. Valdez-Nuñez (iD) https://orcid.org/0000-0002-2513-8423

\section{References}

Alvarado-Herrejón, M.; Larsen, J.; Gavito, M.E.; Jaramillo-López, P.F.; Vestberg, M.; MartínezTrujillo, M.; Carreón-Abud, Y. 2019. Relation between arbuscular mycorrhizal fungi, root-lesion nematodes and soil characteristics in maize agroecosystems. Applied Soil Ecology 135: 1-8.

Alguacil, M.M.; Torres, M.P.; Montesinos-Navarro, A.; Roldán, A. 2016. Soil characteristics driving arbuscular mycorrhizal fungal communities in semiarid Mediterranean soils. Applied and Environmental Microbiology 82: 3348-3356.

Banni, A.S.; Faituri, M.Y. 2013. The role of arbuscular mycorrhizae Glomus spp (mixed) and Glomus fasciculatum in growth and copper uptake of maize grown in soil contaminated with copper. MiddleEast Journal of Scientific Research 17: 77-83.

Basu, S.; Rabara, R.C.; Negi, S. 2018. AMF: The future prospect for sustainable agriculture. Physiological and Molecular Plant Pathology 102: 36-45.

Becerra, A.; Bartoloni, N.; Cofré, N.; Soteras, F.; Cabello, M. 2014. Arbuscular mycorrhizal fungi in saline soils: Vertical distribution at different soil depth. Brazilian Journal of Microbiology 45: 585594.
Cardoso E.J.B.N.; Nogueira M.A.; Zangaro W. 2017. Importance of Mycorrhizae in tropical soils. In: de Azevedo J.; Quecine M. (eds) Diversity and benefits of microorganisms from the Tropics. Springer, Cham.

Carranza, U.L.; Gallardo, L.J.P.; Vidal, C.R. 2012. Las barreras al crecimiento económico en San Martin. Banco Interamericano de Desarrollo, ediciones Nova Print S.A.C., Lima, Perú. 150 pp.

Chen, X.W.; Kang, Y.; So, P.S.; Ng, C.W.W.; Wong, M.H. 2018. Arbuscular mycorrhizal fungi increase the proportion of cellulose and hemicellulose in the root stele of vetiver grass. Plant and Soil 425: 309-319.

Chen, Y.; Yuan, J.G.; Yang, Z.Y.; Xin, G.R.; Fan, L. 2008. Associations between arbuscular mycorrhizal fungi and Rhynchrelyrum repens in abandoned quarries in southern China. Plant and Soil 304: 257-266.

Coelho, I.R.; Pedone-Bonfim, M.V.L.; Silva, F.S.B.; Maia, L.C. 2014. Optimization of the production of mycorrhizal inoculum on substrate with organic fertilizer. Brazilian Journal of Microbiology 45: 1173-1178.

Corpoica (Corporación Colombiana de Investigación Agropecuaria Regional). 1998. Las micorrizas como alternativa al menejo sostenible de los agroecosistemas tropicales. Colombia. Meta, Villavicencio, 6-27 pp.

Duval, M.E.; Capurro, J.E.; Galantini J.A.; Andriani, J.M. 2015. Utilización de cultivos de cobertura en monocultivo de soja: efectos sobre el balance hídrico y órgánico. Ciencia del suelo 33: 247-261

García-González, I.; Quemada, M.; Gabriel, J.L.; Hontoria, C. 2016. Arbuscular mycorrhizal fungal activity responses to winter cover crops in a sunflower and maize cropping system. Applied Soil Ecology 102: 10-18.

Gerdemann, J.W.; Nicolson, T.H, 1963. Spores of mycorrhizal Endogone species extracted from soil by wet sieving and decanting. Transactions of the British Mycological Society 46: 235-244.

Giovannetti, M.; Mosse, B. 1980. An evaluation of techniques for measuring vesicular arbuscular mycorrhizal infection in roots. New Phytologist 84: 489-500.

Haro, H.; Sanon, K.B. S.; Le Roux, C.; Duponnois, R.; Traoré, A.S. 2018. Improvement of cowpea productivity by rhizobial and mycorrhizal inoculation in Burkina Faso. Symbiosis 74: 107-120.

Higo, M.; Isobe, K.; Matsuda, Y.; Ichida, M.; Torigoe, Y. 2015. Influence of sowing season and host crop identity on the community structure of arbuscular mycorrhizal fungi colonizing roots of two different gramineous and leguminous crop species. Advances in Microbiology 5: 107-116.

INVAM. 2017. International Culture Collection of (Vesicular) Arbuscular Mycorrhizal Fungi. Available in: http:/linvam.caf.wvu.edu

Islas A.J.T.; Guijarro K.H.; Eyherabide M.; Rozas H.R.S.; Echeverría H.E.; Covacevich F. 2016. Can soil properties and agricultural land use affect arbuscular mycorrhizal fungal communities indigenous from the Argentinean Pampas soils? Applied Soil Ecology 101: 47-56.

Lopes, L.P.; Varón-López, M.; Gonçalves de Oliveira Prado, I.; Valentim dos Santos, J.; Fonsêca Sousa Soares, C.R.; Siqueira, J.O.; de Souza Moreira, F. M. 2016. Enrichment of arbuscular mycorrhizal fungi in a contaminated soil after rehabilitation. Brazilian Journal of Microbiology 47: 853-862.

López-Gómez, B.F.; Alarcón, A.; Quintero-Lizaola, R.; Lara-Herrera, A. 2015. Selección de cepas de hongos micorrízicos arbusculares en dos sistemas de producción de chile. Revista Mexicana de Ciencias Agrícolas 6: 1203-1214.

Ma, X.; Luo, W.; Li, J.; Wu, F. 2019. Arbuscular mycorrhizal fungi increase both concentrations and bioavilability of $\mathrm{Zn}$ in wheat (Triticum aestivum $\mathrm{L}$ ) 
grain on Zn-spiked soils. Applied Soil Ecology 135: 91-97.

Majewska, M.L.; Rola, K.; Stefanowicz, A.M.; Nobis, M.; Błaszkowski, J.; Zubek, S. 2018. Do the impacts of alien invasive plants differ from expansive native ones? An experimental study on arbuscular mycorrhizal fungi communities. Biology and Fertility of Soils 54: 631-643.

Martín, G.M.; Costa, R.J.R.; Urquiaga, S.; Rivera, R.A. 2007. Rotación del abono verde Canavalia ensiformis con maíz y micorrizas arbusculares en un suelo nitisol ródico éutrico de Cuba. Agronomía tropical 57: 313-321.

Mickan, B.S.; Abbott, L.K.; Solaiman, Z.M.; Mathes, F.; Siddique, K.H.M.; Jenkins, S.N. 2018. Soil disturbance and water stress interact to influence arbuscular mycorrhizal fungi, rhizosphere bacteria and potential for $\mathbf{N}$ and $\mathrm{C}$ cycling in an agricultural soil. Biology and Fertility of Soils 55: 53-66.

Mora-Romero, G.A.; Cervantes-Gámez, R.G.; GalindoFlores, H.; Gonzalez-Ortiz, M.A.; Felix-Gastélum, R.; Maldonado-Mendoza, I.E.; Salinas, P.R.; Leon-Felix, J.; Martinez-Valuenzuela, M.C.; Lopez-Meyer, M. 2015. Mycorrhiza-induced protection against pathogens is both genotype-specific and grafttransmissible. Symbiosis 66: 55-64.

Oehl, F.; Sieverding, E.; Ineichen, K.; Mader, P.; Boller, T.; Wiemken, A. 2003. Impact of land use intensity on the species diversity of arbuscular mycorrhizal fungi in agroecosystems of Central Europe. Applied and Environmental Microbiology 69: 2816-2824.

Oliveira, A.N.; Oliveira, L.A. 2005. Seasonal dynamics of arbuscular mycorrhizal fungi in plantas of Teobroma grandiflorum schum and Paullinia cupana Mart. of an agroforestry system in Central Amazonía, Amazonas State, Brazil. Brazilian Journal of Microbiology 36: 262-270.

Peng, S.; Guo, T.; Liu, G. 2013. The effects of arbuscular mycorrhizal hyphal networks on soil aggregations of purple soil in southwest China. Soil Biology and Biochemistry 57: 411-417.

Peña-Venegas, C.P.; Arias, J.C. 2009. Las leguminosas amazónicas y su importancia en la recuperación de suelos. Revista colombiana Amazónica 2: 161-172.

Peña-Venegas, C.P.; Cardona, G.I.; Mazorra, A.; Arguellez, J.H.; Arcos, A.L. 2006. Micorrizas arbusculares de la amazonia colombiana. Catálogo llustrado. Instituto Amazónico de Investigaciones Científicas SINCHI. Colombia. 90 pp.

Pérez-Luna, Y.C.; Alvarez-Solis, J.D.; Mendoza-Vega, J.; Pat-Fernandez, J.M.; Gómez-Álvarez, R.; Cuevas, L. 2012. Diversidad de hongos micorrícicos arbusculares en maíz con cultivo de cobertura y biofertilizantes en Chiapas, México. Gayana Botánica 69: 46-56.

Rajtor, M., Piotrowska-Seget, Z. 2016. Prospects for arbuscular mycorrhizal fungi (AMF) to assist in phytoremediation of soil hydrocarbon contaminants. Chemosphere 162: 105-116.

Ravikumar, A.; Sears, R.R.; Cronkleton, P.; Menton, M.; Pérez-Ojeda del Arco, M. 2017. Is small-scale agriculture really the main driver of deforestation in the Peruvian Amazon? Moving beyond the prevailing narrative. Conservatios Letters 10: 170-177.

Rojas-Mego, K.C.; Elizarbe-Melgar, C.; Gárate-Díaz, M.H.; Ayala-Montejo, D.; Ruíz-Cubillas, P.; Sieverding, E. 2014. Hongos de micorriza arbuscular en tres agroecosistemas de cacao (Theobroma cacao L.) en la Amazonía peruana. Folia Amazónica 23: 149-156.
SAS Institute Inc. 2008. SAS/STAT 9.2 User's Guide. Cary, NC: SAS Institute Inc. Available in: https://support.sas.com/documentation/cdl/en/statu gintroduction/61750/PDF/default/statug introduction.pdf

Schenck, N.C.; Pérez, Y. 1990. Manual for the Identification of VA Mycorrhizal Fungi. Third edition. Synergistic Publications, Gainesville, Florida, USA.

SENAMHI. 2016. Servicio Nacional de Meteorología e Hidrología del Perú. Estación meteorológica de Tarapoto, San Martin, Perú.

Singh, J.S. 2015. Microbes: the chief ecological engineers in reinstating equilibrium in degraded ecosystems. Agriculture, Ecosystems and Environment 203: 80-82.

Sousa, C.S.; Menezes, R.S.C.; Sampaio, E.V.S.B.; Lima, F.S.; Maia, L.C.; OehI, F. 2014. Arbuscular mycorrhizal fungi in successional stages of caatinga in the semi-arid region of Brazil. Ciência Florestal 24: 137-148.

Stover, H.J.; Naeth, M.A.; Boldt-Burisch, K. 2018. Soil disturbance changes arbuscular mycorrhizal fungi richness and composition in a fescue grassland in Alberta Canada. Applied Soil Ecology 131: 29-37.

Stürmer, S.L.; Siqueira, J.O. 2011. Species richness and spore abundance of arbuscular mycorrhizal fungi across distinct land uses in Western Brazilian Amazon. Mycorrhiza 21: 255-267.

Suazo-Ortuño, I.; Lopez-Toledo, L.; Alvarado-Diaz, J.; Martinez-Ramos, M. 2015. Land-use change dynamics, soil type and species forming mono-dominant patches: the case of Pteridium aquilinum in a neotropical rain forest region. Biotropica 4: 18-26.

Thougnon-Islas, A. J.; Eyherabide, M.; Echeverría, H. E.; Sainz Rosas, H. R.; Covacevich, F. 2014. Capacidad micotrófica y eficiencia de consorcios con hongos micorrícicos nativos de suelos de la Provincia de Buenos Aires con manejo contrastante. Revista Argentina de Microbiologia 46(2): 133-143.

Torres-Arias, Y.; Ortega, R.F.; Nobre, C.; Furrazola, E.G.; Louro, R.L.B. 2017. Production of native arbuscular mycorrhizal fungi inoculum under different environmental conditions. Brazilian Journal of Microbiology 48: 87-9.

Turrini, A.; Bedini, A.; Loor, M.B.; Santini, G.; Sbrana, C.; Giovannetti, M.; Avio, L. 2018. Local diversity of native arbuscular mycorrhizal symbionts differentially affects growth and nutrition of three crop plant species. Biology and Fertility of Soils 54: 203-217.

Vallejo-Quintero, V.E. 2013. Importancia y utilidad de la evaluación de la calidad de suelos mediante el componente microbiano: experiencias en sistemas silvopastoriles. Colombia Forestal 16: 83-99.

van der Heijden, M.G.A.; Martin, F.M.; Selosse, M.-A.; Sanders, I.R. 2015. Mycorrhizal ecology and evolution: the past, the present and the future. New Phytologist 205: 1406-1423.

Vierheilig, H.; Coughlan, A.P.; Wyss, U.; Piché, Y. 1998. Ink and vinegar, a simple staining technique for arbuscular-mycorrhizal fungi. Applied and Environmental Microbiology, Baltimore 64: 50045007. 